\title{
The Group of 77, UNCTAD V and the North/South Dialogue
}

\section{Marc A. Williams}

UNCTAD $V$ has left many commentators seriously disillusioned about the prospects for real progress in the North/South dialogue. The Conference is judged to have been a failure because it did not agree on any significant measure which would lead to a rise in the standard of living of the poor peoples of the world. It was also distinguished by an open and public squabble among the members of the Group of $77 .^{1}$ Conflicts of interest amongst them are not new, but at Manila the widespread disagreement seriously affected the work of the Conference. This article is an attempt to analyse the politics of the Group of 77 within the context of the North/South debate.

\section{The North/South Dialogue}

Although the term 'North/South dialogue' is generally used solely in connection with those talks which have taken place since 1973, a concerted attempt by the developing countries to reform the international economic order can be dated from the first UNCTAD Conference in 1964. It was here that, with an impressive display of solidarity, they first presented a series of linked demands for wide-ranging changes in international economic relations. The events since 1973 have merely been an intensification of a process begun a decade earlier.

The actions of a group of Third World commodity producers (oil exporters) to determine unilaterally the price paid for their commodity sent shock waves through the international political and economic systems. To many commentators, at the time and since, it constituted an event of great significance. ${ }^{2}$ Whatever other consequences the OPEC action had, it certainly affected the perceptions of the state actors in the international economy and led directly to the initiation of what is known as the North/ South dialogue. The developed countries were sufficiently alarmed to agree to the convening of a Special Session of the UN General Assembly and to accuiesce in the resolutions passed there.

\footnotetext{
1 The group currently consists of 119 members.

2 For example see Barraclough (1976: 31), where he talks of 'a watershed of history'.
}

They feared that unless something was done, or at least the appearance given that some action was forthcoming, other developing countries might follow OPEC's action. Subsequent events have proved this fear unjustified. Although OPEC still enjoys considerable success, the prospect of future Third World commodity cartels exercising sufficient control to imitate OPEC has receded. Consequently, the developed countries now feel less need to respond to Third World demands, and the economic recession has seen them turning inwards. $^{3}$ In the last three years they have become increasingly protectionist.

Within the North/South dialogue the main conferences have been CIEC, UNCTAD IV and UNCTAD V. Progress has been slow and there have been few concrete results from the developing countries' attempts to create a New International Economic Order (NIEO)."

In pursuit of a NIEO, the developing countries have made a three-pronged attack on the present trading system and sought: (i) to change the intellectual climate and to gain acceptance for certain ideas thought to favour their economic development, such as the acceptance of specific aid targets and special treatment for the economically disadvantaged; (ii) to negotiate specific economic agreements, e.g. the Generalised System of Preferences (GSP) and the Integrated Programme for Commodities (IPC); and (iii) to create new international economic institutions or to restructure existing ones in order to implement measures favourable to the developing countries, such as the IMF's Committee on Reform of the International Monetary System. This three-pronged attack thus embraces a wide spectrum of objectives, including increases in the price and volume of developing country exports, the achievement by developed countries of the agreed goal of 0.7 per cent of GNP in development assistance, greater control over the activities of TNCs, increased access to technology and to capital markets, and a reform of the international monetary system.

\footnotetext{
3 Note the increasing number of summit meeting held exclusively among the leaders of the foremost trading nations.

4 For the record of attempts to create a NIEO, see UN $(1974,1974 a, 1975$ and $1975 a)$.
} 
These demands assume a distortion in the international trading system. Despite differences in political and economic ideologies and in economic strategies, the 77 are united in their condemnation of the present international economic system. This has provided a rallying point and a basis for solidarity vis-à-vis the developed countries. As the present UNCTAD Secretary General has written,

For these countries the compelling need for a new order is not based on the consideration that the prevailing order is no longer working well. It is based on the more fundamental premise that the prevailing order did not satisfy their needs even when it was working best. (UNCTAD 1976: 3, para 7.)

\section{The Group of Seventy-Seven}

The Group of 77 is a highly institutionalised but informal organisation of developing countries which acts primarily as a pressure group in the Third World struggle for political and economic change in the structure of the world economy. The group is informal in the sense that it has no headquarters, no constitution and no written rules of procedure. Its high degree of institutionalisation within UNCTAD is a function of the group system which grew out of the political differences at the 1964 Conference. For electoral purposes states were divided into four lists which reflected geographic and socio-economic factors. ${ }^{5}$ The Group of 77 is divided into three regional subgroups-African, Asian and Latin American. Coordination takes place first at the regional level, and the agreed regional positions are then compared to produce a common group position. This process takes place on a continuing basis and before every UNCTAD Conference a meeting at ministerial level is held. ${ }^{6}$

The degree of unity and coordination which emerged at the 1964 Conference thus predated the North/South dialogue, and in fact began in the late 1950s with, for example, cooperation on international economic issues such as the abortive SUNFED. (For much of the 1950s, Cold War alignments had meant that developing countries were found on opposing sides during economic debates, but-from about 1958--they had slowly begun to find a common negotiating position

\footnotetext{
5 See the UN General Assembly Resolution 1995 (XIX) of December 1964 which established UNCTAD as a permanent

becember 1964 which established UNCTAD as a permanent
b The first. second and third Ministerial Meetings were held at Algiers. Lima and Manila before UNCTAD I. II and III respectively.
}

within the UN and GATT.) ${ }^{7}$ The significance of 1964 was that it established a framework to enable this unity to continue after the Conference ended.

Despite the changes in international relations since 1964, the basic premise which produced the Group still operates and provides the key to its politics. This is that the shared interests of members transcend the differences between them and differentiate them as a group. These shared characteristics reflect the member states' position in the international economy, their levels of economic development, and their relative impotence to affect international policy when acting singly. On the assumption that a coalition might be able to wrest concessions from the industrialised nations where an individual country could not, solidarity became the leit-motif of the 77. The weakness which forced the developing countries to unite in the first instance keeps them united today.

Yet behind the outward show of solidarity there are inherent conflicts which sometimes surface, as at Manila. The most distinctive feature of the Group of 77, apart from its unity, is the divergence in levels of development, types of economy, and political and economic philosophies amongst its membership. Any group of over 100 states which attempts to reach common agreement on such a wide range of economic issues must have internal tensions and find it difficult sometimes to reconcile the various positions. Since 1964 the membership of the Group has increased by 42 and some countries have made significant economic gains whilst others have made little perceptible progress or have regressed. There are differences both between and within the regional groups. The greatest constraint on effective solidarity is the manifest economic diversity: as between the higher income countries (eg. Brazil, Mexico and Argentina) and the lower income countries (eg. Tanzania, Bangladesh and Chad); as between the oil exporters and the rest; as between those countries with strong manufacturing export sectors (eg. Taiwan, Singapore and Brazil) and those without; and as between the larger more diversified economies and the smaller monocultural ones.

The general method of reconciling the different interests is to aggregate them into a composite resolution which accommodates all viewpoints. This is not always possible, however, since

\footnotetext{
T For the background to UNCTAD I see Cordovez (1967).
} 
different demands may be irreconcilable. In these cases the Group cannot proceed as quickly as its members would wish, since efforts have to be made to resolve conflicts and find an acceptable compromise. For example, the negotiations leading to the conclusion of an agreement on the creation of a GSP were stymied not only by developed country opposition but also by a conflict between those developing countries enjoying selective preference treatment, particularly the African associates of the European Community who wanted equivalent advantages under any new system, and those countries, led by Argentina, Brazil and Chile, who argued for the immediate dissolution of the selective preference schemes. The evolution of the Integrated Programme and the Common Fund also reflected intra-77 tensions. A distinction can be made between those members of the 77 who wanted a restricted programme centred on a few commodities and with limited aims (e.g. Argentina, Brazil and Indonesia) and those who wanted a more ambitious programme (e.g. the African Group (Goodwin and Mayall 1977: 152). As the negotiations developed a third group of countries emerged whose interest in the Common Fund was to limit any adverse effects it might have on their economies, e.g. India, Pakistan and Sri Lanka. The 77 committed to solidarity did not abandon the attempts at an Integrated Programme or a Common Fund but sought instead to reconcile these differences. The result was an umbrella resolution which papered over the significant differences between countries. ${ }^{8}$

\section{UNCTAD V}

UNCTAD $V$ was the latest round in the North/ South dialogue. The omens for the success of the Conference were not good since it was held in a most unfavourable international climate. The world economy is currently experiencing its worst period since the end of the Second World War. In a time of rising protectionism, mounting energy prices and global recession, the developed countries are not only disinclined to be charitable, but place short-term self interest before more enlightened policies which would aid both themselves and the developing countries. Since 1976 the developed countries have increasingly turned inward and the recent conclusion of the Multilateral Trade Negotiations (MTN) show how little they are prepared to respond to Third World demands. As originally

\footnotetext{
B On the development of the IPC in response to the
} differences within the 77 see Rangarajan (1978: 294-305). conceived in the Tokyo Declaration of September 1973, the MTN had two related objectives. First, to liberalise world trade, and secondly to secure additional benefits for the international trade of the developing countries through a substantial improvement in the conditions of access for the products of interest to the developing countries and, where appropriate, to initiate measures designed to attain stable, equitable and remunerative prices for primary products. Yet, in the event, the developing countries were largely excluded from the negotiating process and presented with a completed text which erodes their preferential margins under the GSP. Moreover, Britain and France are threatening to impose selective import controls against countries whose exports are deemed to be 'disruptive', whether this is sanctioned by GATT or not. ${ }^{9}$ Further, it is the developing countries which have been hardest hit by the rise in energy prices and the increasing protectionism of the rich countries.

In the light of all this, it would have been folly to expect UNCTAD $\mathrm{V}$ to produce any real measure of agreement between the two sides. This places the unity of the 77 even more at a premium. But the present economic crisis has also widened some of the divisions within the 77 , particularly between the oil-exporting nations and the oil-importing nations. The fourth Ministerial Meeting of the 77 was held at Arusha, Tanzania, from 6-16 February 1979 and adopted the Arusha Programme for Collective Self-Reliance and Framework for Negotiations (UNCTAD (1) 1979). The purpose of the Ministerial Meeting was to coordinate the positions of the three regional groups and to obtain a measure of unity and a common negotiating position before the Manila Conference. To achieve this, the Arusha Programme papered over the cracks, and some developing countries, most notably Brazil, South Korea and Argentina, were unhappy with the result.

At Manila some of these latent differences came out into the open. The major cause of dissension was the insistence of the Latin American countries, led by Costa Rica backed by Argentina and Brazil, that energy should be placed on the agenda, a move which was resisted by the major oil exporters. The Latin American countries were openly critical of the oil price rise and the damage it was inflicting on the economies of the oil importing developing

\footnotetext{
9 So far the only developing countries to have ratified the agreement are Argentina and Romania.
} 
countries. Latin American anger was fuelled not only by their increased import bills but also by the failure of the oil-rich states to adopt a more sympathetic attitude to their fellow members of the 77 , more particularly those who have neither very low per capita GDP nor very large Moslem communities. The split within the ranks of the 77 was further aggravated by the support given to the Latin Americans by the Group $B$ countries. This dispute, which continued until the final week of the Conference, seriously affected the ability of the 77 to reach common positions on other issues. The other major split in the 77 was caused by a proposal sponsored by Kuwait and Qatar to phase out flags of convenience. This was vehemently opposed by many 77 members who saw it as injurious to their interests. Liberia led the opposition and was supported by Panama, Cyprus, India, Taiwan, Singapore and the Philippines. ${ }^{10}$

With such a long and complex agenda there was inherent scope for conflict among this large and heterogeneous group of countries. The wider the range of issues, the greater the diversity of interests and hence the more difficult it became to reconcile conflicting positions. In assessing the unity of the 77 after Manila it should be remembered that at all UNCTAD Conferences some of the latent divisions within the Group have surfaced, whether publicly-as at Manilaor privately. At UNCTAD I the institutionalisation issue posed problems for solidarity. At UNCTAD II, preferences and the least developed countries were the major areas of disagreement. At UNCTAD III it was the least developed, relations with the European Community and monetary relations that were stumbling blocks; and at Nairobi, the Integrated Programme. However, the conflict within the 77 at Manila differed in one significant way from previous ones. In past conflicts the focus has been on resources held by the developed countries, and at issue were differences over strategy or the distribution of these resources between developing countries. This time the main dispute arose over resources held by the developing countries themselves. In the past, differences could be resolved by the aggregation of the various demands into a composite draft resolution, but this proved

10 A Liberian delegate referred to the move as 'an A rab plot to control world oil transport' (The Economist, 26 May-1 June 1979: 97). impossible at Manila. It is difficult at this juncture to predict exactly how this new development will affect the 77's bargaining strategy and solidarity, but it does provide a serious area of disagreement and potential coalition-breaking. On the other hand, the feeble results of Manila have brought into question the whole feasibility of negotiated structural change in the world economy. For the 77, Manila has once again demonstrated that without solidarity they have little hope of wresting significant concessions from the rich countries, but that even with solidarity their gains are minimal.

\section{References}

Barraclough, Geoffrey, 1976, 'The Haves and the Have-nots', New York Review of Books, 13 May

Cordovez, D., 1967, 'The Making of UNCTAD', Journal of World Trade Law, vol. 1 no. 1, May-June

Goodwin, Geoffrey and James Mayall, 1977, 'The Political Dimensions of the UNCTAD Integrated Commodity Scheme', Millenium, Journal of International Studies, vol. 6 no. 2, Autumn

Rangarajan, L.N., 1978, Commodity Conflict, Croom Helm, London

UN, 1974, Declaration on the Establishment of a New International Economic Order, General Assembly Resolution 3201 (S-VI), New York, May

-1974a, Programme of Action on the Establishment of the New International Economic Order, General Assembly Resolution 3202 (S-VI), New York, May

-1975, Charter of the Economic Rights and Duties of States, General Assembly Resolution 3281 (XXIX), New York, January

-1975a, Development and International Cooperation, General Assembly Resolution 3362 (S-VII), New York, September

UNCTAD, 1976, New Directions and New Structures for Trade and Development, (TD 183), Geneva

-(1) 1979 , see Editorial references 